\title{
PERBANDINGAN PENGUJIAN AKTIVITAS ANTIBAKTERI STARTER YOGURT DENGAN METODE DIFUSI SUMURAN DAN METODE DIFUSI CAKRAM
}

\author{
COMPARISON OF THE ANTIBACTERIAL ACTIVITY OF YOGURT \\ STARTER WITH DISK DIFFUSION AGAR AND WELL DIFUSSION AGAR \\ METHODS
}

\begin{tabular}{|c|c|}
\hline $\begin{array}{l}\text { Received } \quad: \quad \text { May } 28^{\text {th }} 2020 \\
\text { Accepted }\end{array}$ & $\begin{array}{l}\text { Abstract. Antibacterial activity testing can be done using the } \\
\text { agar diffusion method, including agar well difussion and } \\
\text { disk diffusion agar methods. This study aims to compare }\end{array}$ \\
\hline $\begin{array}{l}\text { Lilih Siti Nurhayati' } \\
\text { Nadhira Yahdiyani, }^{* 1}, \\
\text { Akhmad Hidayatulloh }^{1}\end{array}$ & $\begin{array}{l}\text { two antibacterial testing methods to analyze the ant1- } \\
\text { bacterial activity of a yogurt starter against the bacteria } \\
\text { Eschericia coli and Staphilococcus aureus. The study was } \\
\text { conducted experimentally with } 5 \text { concentrations of yogurt }\end{array}$ \\
\hline $\begin{array}{l}\text { 'Fakultas Peternakan, } \\
\text { Universitas Padjadjaran, } \\
\text { Sumedang. }\end{array}$ & $\begin{array}{l}\text { starter, namely } 2 \%, 4 \%, 6 \%, 8 \% \text {, and } 10 \% \text {. Testing } \\
\text { antibacterial activity using two methods ,disk diffusion agar } \\
\text { and well difussion agar methods. The research showed that }\end{array}$ \\
\hline${ }^{*}$ Korespondensi: & $\begin{array}{l}\text { greater than the disk diffusion method for } E \text {. coli and } S \text {. } \\
\text { aureus. }\end{array}$ \\
\hline $\begin{array}{l}\text { Laboratorium Riset dan } \\
\text { Pengujian Bioteknologi, } \\
\text { Fakultas Peternakan } \\
\text { Universitas Padjadjaran. }\end{array}$ & $\begin{array}{l}\text { Keywords: well method, disk method, E. coli, S. aureus, } \\
\text { antibacterial. }\end{array}$ \\
\hline $\begin{array}{l}\text { Jalan Raya Bandung- } \\
\text { Sumedang KM } 21 \\
\text { Jatinangor, Sumedang. } \\
45363 .\end{array}$ & $\begin{array}{l}\text { Sitasi: } \\
\text { Nurhayati, L. S., Yahdiyani, N., \& Hidayatulloh, A. (2020). } \\
\text { Perbandingan Pengujian Aktivitas Antibakteri Starter } \\
\text { Yogurt dengan Metode Difusi Sumuran dan Metode Difusi } \\
\text { Cakram. Jurnal teknologi Hasil Peternakan, 1(2):41-46. }\end{array}$ \\
\hline
\end{tabular}

\section{PENDAHULUAN}

Senyawa antibakteri adalah senyawa kimiawi atau biologis baik alami maupun sintetik yang dapat menghambat pertumbuhan dan aktivitas bakteri. Yogurt merupakan bahan pangan hasil fermentasi yang menggunakan bakteri asam laktat (BAL) sebagai starter pada proses pembuatannya dan telah banyak dipelajari bahwa BAL yang terdapat pada starter yogurt tersebut memiliki aktivitas antibakteri.

Kemampuan BAL menghasilkan aktivitas antimikroba karena BAL dapat memproduksi beberapa senyawa antibakteri selama proses fermentasi yaitu asam organik (asam laktat dan asam asetat), diasetil, etanol, hidrogen peroksida, reuterin, asetaldehid, ase- toin, karbon dioksida, dan bakteriosin yang dapat menghambat pertumbuhan mikroba patogen (Mayo et al., 2010; Garcia-Cano et al., 2014). Pada penelitian yang dilakukan oleh Gawad et al. (2014), yogurt yang diproduksi menggunakan starter Streptococcus thermophilus, Lactobacillus bulgaricus, dan Bifidobacterium longum memiliki aktivitas antibakteri terhadap bakeri patogen yaitu Eschericia coli dan Staphilococcus aureus.

Aktivitas antibakteri dapat dipelajari menggunakan beberapa metode, yaitu metode dilusi, metode difusi agar, dan metode difusi dilusi. Metode difusi adalah metode yang sering digunakan untuk analisis aktivitas antibakteri. Ada 3 cara dari metode difusi yang 
dapat dilakukan yaitu metode sumuran, metode cakram, dan metode silinder (Pratiwi, 2008). Prinsip kerja metode difusi adalah terdifusinya senyawa antibakteri ke dalam media padat dimana mikroba uji telah diinokulasikan. Hasil pengamatan yang diperoleh berupa ada atau tidaknya daerah bening yang terbentuk di sekeliling kertas cakram yang menunjukan zona hambat pada pertumbuhan bakteri (Balaouri et al., 2016).

Metode sumuran dilakukan dengan membuat lubang yang dibuat tegak lurus pada agar padat yang telah diinokulasi dengan bakteri uji. Jumlah dan letak lubang disesuaikan dengan tujuan penelitian, kemudian lubang diisi dengan sampel yang akan diuji. Setelah dilakukan inkubasi, pertumbuhan bakteri diamati untuk melihat ada tidaknya daerah hambatan di sekeliling lubang (Pelzcar, 2006). Metode sumuran memiliki kelebihan yaitu lebih mudah mengukur luas zona hambat yang terbentuk karena bakteri beraktivitas tidak hanya di permukaan atas nutrien agar tetapi juga sampai ke bawah. Pembuatan sumuran memiliki beberapa kesulitan seperti terdapatnya sisa-sisa agar pada suatu media yang digunakan untuk membuat sumuran, selain itu juga besar kemungkinan media agar retak atau pecah disekitar lokasi sumuran sehingga dapat mengganggu proses peresapan antibiotik ke dalam media yang akan memengaruhi terbentuknya diameter zona bening saat melakukan uji sensitivitas.

Metode difusi menggunakan cakram dilakukan dengan cara kertas cakram sebagai media untuk menyerap bahan antimikroba dijenuhkan ke dalam bahan uji. Setelah itu kertas cakram diletakkan pada permukaan media agar yang telah diinokulasi dengan biakan mikroba uji, kemudian diinkubasikan selama 18-24 jam pada suhu $35^{\circ} \mathrm{C}$. Area atau zona bening di sekitar kertas cakram diamati untuk menunjukkan ada tidaknya pertumbuhan mikroba. Diameter area atau zona bening sebanding dengan jumlah mik- roba uji yang ditambahkan pada kertas cakram (Bonang, 1992). Kelebihan dari metoda cakram yaitu dapat dilakukan pengujian dengan lebih cepat pada penyiapan cakram (Listari, 2009).

Penelitian mengenai perbandingan metode sumuran dan cakram masih sedikit dilakukan, oleh karena itu penelitian ini bertujuan untuk membandingkan dua metode pengujian tersebut untuk menganalisis aktivitas antibakteri dari starter yogurt terhadap bakteri Eschericia coli dan Staphilococcus aureus.

\section{MATERI DAN METODE}

Penelitian dilakukan adalah penelitian metode eksperimental, dengan objek penelitian adalah starter yogurt (Streptococcus thermophilus, Lactobacillus bulgaricus, Lactobacillus acidophillus) pada 5 konsentrasi yaitu 2\%, 4\%, 6\%, 8\%, dan $10 \%$ setiap perlakuan diulang sebanyak 3 kali dengan parameter pengujian aktivitas antibakteri terhadap bakteri Eschericia coli dan Staphilococcus aureus. Hasil yang diperoleh kemudian dihitung rata-ratanya.

\section{Alat dan Bahan Penelitian}

Peralatan yang digunakan pada penelitian adalah autoclave, blue tips, cawan petri, gelas ukur, hockey stick, inkubator, jangka sorong, jarum ose, kertas cakram, labu erlenmeyer, laminar airflow, pembakar bunsen, mikropipet, rak tabung reaksi, refrigerator, tabung reaksi, timbangan analitik, vortex. Bahan yang digunakan pada penelitian adalah antibiotik chloramphenicol, bakteri $E$. coli, bakteri S. aureus, etanol 70\%, Starter yogurt, $\mathrm{NaCl}$ fisiologis $0,9 \%$, media Muller Hinton Agar (MHA, OXOID).

\section{Pembuatan Media MHA}

Pembuatan media Muller Hinton Agar (MHA) dimulai dengan menimbang MHA sebanyak 19 gram dan dilarutkan ke dalam Labu erlenmeyer dengan akuades hingga mencapai volume $500 \mathrm{~mL}$, kemudian dipanaskan hingga homogen. Media disterilisasi menggu- 
nakan autoclave pada suhu $121^{\circ} \mathrm{C}$ selama 15 menit. Tuang media ke dalam cawan petri sekitar $25 \mathrm{~mL}$ dan dibiarkan hingga memadat.

\section{Persiapan Suspensi Bakteri Uji}

Suspensi koloni uji E. coli dan $S$. aureus dibuat dengan cara mengambil satu ose koloni dari media NA padat ke tabung reaksi berisi $5 \mathrm{~mL} \mathrm{NaCl}$ fisiologis. Kekeruhan pada suspensi koloni uji distandarisasi dengan standar 0,5 McFarland (sekitar 1,5 x $10^{8} \mathrm{CFU} / \mathrm{mL}$ ). Suspensi harus digunakan sebagai inokulum dalam waktu 15 menit.

\section{Pengujian Antibakteri Menggu- nakan Metode Sumuran (Poelo- ngan et al., 2006)}

Suspensi bakteri uji diinokulasikan pada media MHA sebanyak 0,1 $\mathrm{mL}$, kemudian diratakan dengan hockey stick dan diamkan hingga kering. Sumuran dibuat dengan menggunakan bagian ujung pipet steril. Dimasukkan starter yogurt sebanyak $40 \mu \mathrm{L}$ ke dalam sumuran yang telah dibuat, selanjutnya inkubasi selama 24 jam pada suhu $37^{\circ} \mathrm{C}$. Diamati zona bening di sekitar sumuran.

5. Pengujian Antibakteri Menggunakan Metode Cakram (Poelongan et al., 2006)

Suspensi bakteri uji diinokulasikan pada media MHA sebanyak 0,1 $\mathrm{mL}$, kemudian diratakan dengan hockey stick dan diamkan hingga kering. Kertas cakram yang telah direndam ke dalam starter yogurt pada masing-masing konsentrasi selama 15 menit kemudian diletakkan pada permukaan media secara aseptik. Diamati zona bening di sekitar kertas cakram.

\section{Analisis Data}

Zona hambat yang merupakan aktivitas antibakteri diukur menggunakan jangka sorong sebanyak tiga kali seperti pada gambar pada posisi yang berbeda dan dirata-ratakan nilainya (Afriani, 2017).

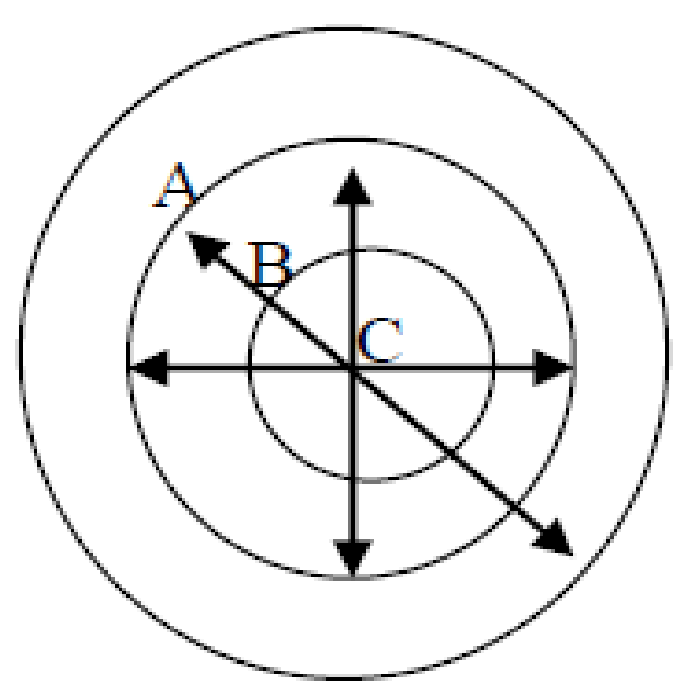

Keterangan :

A : Cawan petri

B : Zona hambat

C : Kertas cakram

$\longleftrightarrow$ : pengukuran zona hambat

\section{HASIL DAN PEMBAHASAN}

Hasil pengujian aktivitas antibakteri terhadap bakteri patogen gram positif yaitu $S$. Aureus dengan perbandingan dua metode yaitu metode cakram dan metode sumuran ditunjukkan pada Tabel 1, sedangkan aktivitas antibakteri terhadap bakteri patogen gram negatif yaitu E. coli ditunjukkan pada Tabel 2. Aktivitas antibakteri terhadap S.aureus yang dihasilkan starter yogurt berkisar pada 1,18 - 1,35 menggunakan metode cakram sedangkan menggunakan metode sumuran berkisar pada $1,33-1,54$.

Aktivitas antibakteri menggunakan metode sumuran lebih tinggi dibandingkan dengan aktivitas antibakteri dengan metode cakram (Gambar 1). Hal ini diduga karena sampel yang dimasukkan kedalam sumuran yang telah dibuat menghasilkan proses osmosis dapat terjadi lebih homogen dan efisien sehingga lebih efektif dalam menghambat pertumbuhan bakteri. 


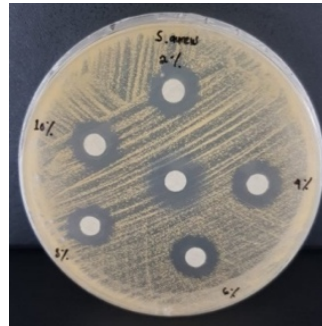

(a)

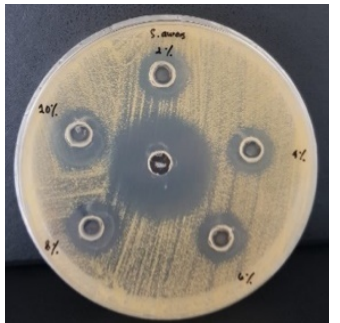

(b)

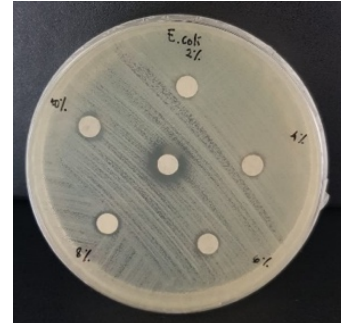

(c)

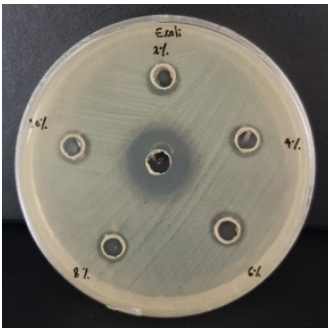

(d)

Gambar 1. Aktivitas Antibakteri Starter Yogurt Terhadap S. aureus; (a) Metode Cakram dan (b) Metode Sumuran dan E. coli; (c) Metode Cakram dan (d) Metode Sumuran.

Tabel 1. Aktivitas Antibakteri Starter Yogurt pada Berbagai Konsentrasi dengan Metode Cakram dan Metode Sumuran Terhadap S. aureus.

\begin{tabular}{ccc}
\hline \multirow{2}{*}{ Sampel } & \multicolumn{2}{c}{ Rataan Aktivitas antibakteri } \\
\cline { 2 - 3 } & Metode Cakram $(\mathrm{mm})$ & Metode Sumuran $(\mathrm{mm})$ \\
\hline Antibiotik (Chloramphenicol) & 1,46 & 3,04 \\
Starter Yogurt Konsentrasi 2\% & 1,18 & 1,33 \\
Starter Yogurt Konsentrasi 4\% & 1,30 & 1,36 \\
Starter Yogurt Konsentrasi 6\% & 1,35 & 1,38 \\
Starter Yogurt Konsentrasi 8\% & 1,36 & 1,40 \\
Starter Yogurt Konsentrasi 10\% & 1,35 & 1,54 \\
\hline
\end{tabular}

Tabel 2. Aktivitas Antibakteri Starter Yogurt pada Berbagai Konsentrasi dengan Metode Cakram dan Metode Sumuran Terhadap E. coli.

\begin{tabular}{ccc}
\hline \multirow{2}{*}{ Sampel } & \multicolumn{2}{c}{ Rataan Aktivitas antibakteri } \\
\cline { 2 - 3 } & Metode Cakram $(\mathrm{mm})$ & Metode Sumuran $(\mathrm{mm})$ \\
\hline Antibiotik (Chloramphenicol) & 1,27 & 2,31 \\
Starter Yogurt Konsentrasi 2\% & 0,75 & 1,09 \\
Starter Yogurt Konsentrasi 4\% & 0,77 & 1,07 \\
Starter Yogurt Konsentrasi 6\% & 0,78 & 1,11 \\
Starter Yogurt Konsentrasi 8\% & 0,86 & 1,03 \\
Starter Yogurt Konsentrasi 10\% & 0,90 & 1,21 \\
\hline
\end{tabular}

Aktivitas antibakteri terhadap $E$. coli yang dihasilkan starter yogurt berkisar pada 0,75 - 0,90 menggunakan metode cakram sedangkan menggunakan metode sumuran berkisar pada $1,03-1,21$. Sama halnya dengan aktivitas antibakteri terhadap $S$. aureus, aktivitas yang dihasilkan pada metode sumuran lebih tinggi dibandingkan dengan aktivitas pada metode cakram. Hal ini sejalan dengan penelitian Sri et al. (2017) yang menyatakan bahwa pengujian aktivitas antibakteri dengan metode sumuran dapat menghasilkan area atau zona hambat yang lebih luas.

Hasil tersebut didukung pula dengan hasil penelitian Ari et al. (2019) yang mempelajari teknik difusi sumu- ran dan cakram untuk mengevaluasi sensitivitas antibiotik terhadap E. coli mendapatkan hasil bahwa dengan metode sumuran diperoleh zona bening antibiotik yang lebih tinggi dibandingkan dengan metode cakram. Zona hambat atau aktivitas antibakteri terhadap $S$. aureus (gram positif) lebih tinggi dibandingkan dengan E. Coli (gram negatif) disebabkan karena pada umumnya bakteri gram negatif mempunyai resistensi yang lebih baik terhadap senyawa antibakteri karena memiliki struktur dinding sel yang lebih kompleks.

Dinding sel bakteri Gram positif sebagian besar tersusun atas peptidoglikan (95\%), sedangkan dinding sel bakteri Gram negatif tersusun atas 
lipidprotein, lipopolisakarida dan hanya mengandung sedikit peptidoglikan (5-10\%). Lapisan lipopolisakarida ini memperkuat kekakuan/rigiditas dinding sel bakteri Gram negatif melalui ikatan silang kationik intermolekuler (Holst, 2011). Hal inilah yang menyebabkan bakteri Gram negatif menjadi lebih kokoh sehingga sulit ditembus oleh senyawa antibakteri dari starter yogurt. Struktur dinding sel bakteri gram positif lebih sederhana sehingga memudahkan senyawa antibakteri masuk ke dalam sel (Septiani et al., 2017).

\section{KESIMPULAN}

Berdasarkan penelitian diperoleh hasil bahwa dengan metode sumuran diperoleh aktivitas antibakteri lebih besar dari pada metode cakram untuk bakteri E. coli maupun S. aureus.

\section{DAFTAR PUSTAKA}

Afriani, N., Yusmarini, \& Usman, P. (2017). Aktivitas Antimikroba Lactobacillus plantarum 1 yang diisolasi dari Industri Pengolahan Pati Sagu Terhadap Bakteri Patogen Escherichia coli FNCC-19 dan Staphylococcus aureus FNCC15. JOM FAPERTA, 4(2).

Ari, K., Yuriska, S., Annisa, Y., \& Kurnia, R. (2019). Uji Teknik Difusi Menggunakan Kertas Saring Media Tampung Antibiotik dengan Escherichia coli sebagai Bakteri Uji. Jurnal Kesehatan Pri$m a, 13(2): 151-155$.

Balouiri, M., Sadiki, M., \& Ibnsouda, S. K. (2016). Methods for In Vitro Evaluating Antimicrobial activity: A review. Journal of Pharmaceutical Analysis, 6(2):71-79.

Bonang, G. (1992). Mikrobiologi Untuk Profesi Kesehatan Edisi 16. Buku Kedokteran EGC. Jakarta.

García-Cano I., Serrano-Maldonado, C. E., Olvera-García, M., DelgadoArciniega, E., Peña-Montes, C.,
Mendoza-Hernández, G, \& Quirasco, M. (2014). Antibacterial Activity Produced by Enterococcus Spp. Isolated From An Artisanal Mexican Dairy Product, Cotija Cheese. LWT-Food Science and Technology, 59:26-34.

Gawad, A. E., Sayed, E., Zeini, E., Hafiez, \& Saleh. (2014). Antibacterial Activity of Probiotic Yoghurt and Soy Yogurt Against Eschericia coli and Staphylococcus aureus. Journal of Nutrition and Food Sciences, 4(5).

Holst, O. (2011). Structure of Lipopolysaccharide Core Region. di dalam: Knirel, Y.A., Valvano, $\mathrm{M}$. A. Editor. Bacterial Lipopolysaccharides: Structure, Chemical Synthesis, Biogenesis, and Interaction. Springer-Verlag. Wina. (AT).

Listari, Y. (2009). Efektifitas Penggunaan Metode Pengujian Antibiotik Isolat Streptomyces dari Rizosferfamilia poaceae terhadap Escherichia coli. Jurnal online, 1-6.

Mayo, B., Aleksandrzak-Piekarczyk, T., Fernndez, M., Kowalczyk, M., Lvarez-Martn, P., \& Bardowski, J. (2010). Updates in the Metabolism of Lactic Acid Bacteria. Biotechnology of Lactic Acid Bacteria, 3-33.

Pelczar, M. J. \& Chan, E. C. S. (2006). Dasar-Dasar Mikrobiologi Jilid 2. UI Press. Jakarta.

Poelongan, M., Chairul, Komala, I., Salmah, S., \& Susan, M. N. (2006). Aktivitas Antimikroba dan Fitokimia dari Beberapa Tanaman Obat. Seminar Nasional Teknologi Peternakan dan Veteriner.

Pratiwi, R. (2008) Perbedaan daya hambat terhadap Streptococcus 
mutans daribeberapa pasta gigi yang mengandung herbal. Majalah Kedokteran Gigi, 38(2) : 64 - 67.

Septiani, Eko, N. D., \& Ima, W. (2017). Aktivitas Antibakteri Ekstrak Lamun (Cymodocea rotundata) Terhadap Bakteri Staphylococcus aureus dan Escherichia coli. Saintek Perikanan, 13(1):1-6.

Sri, D. H., Sri, D., \& Wildiani, W. (2017). Perbandingan Efek Ekstrak Buah
Alpukat (Persea americana mill) Terhadap Pertumbuhan Bakteri Pseudomonas aeruginosa dengan Metode Disk dan Sumuran. Seminar Nasional Publikasi HasilHasil Penelitian dan Pengabdian Masyarakat 2017. Universitas Muhammadiyah Semarang. 348.

Tenovar, F. C. (2006). Mechanism of Antimicrobial Resistance in bacteria. American Journal of Infection Control, (34):3-10. 